\title{
Evaluasi Implementasi Kurikulum 2013 Mata Pelajaran Biologi Di SMA Negeri
}

\author{
Yohana Makaborang \\ Pendidikan Biologi Fakultas Ilmu-Ilmu Sosial Universitas Kristen Wira Wacana Sumba \\ yohanamakaborang89@gmail.com
}

\begin{abstract}
The study intends to evaluate the 2013 curriculum of biological subjects at SMAN 1 Waingapu. Evaluative research is a type of research. Data collection, data reduction, data display, and data conclusion are techniques in data analysis, while data collection techniques are conducted with document studies, observations, and interviews. The principal, Wakasek curriculum, biology teachers, and students are the subject of research. Legitimacy of data by using source triangulation and triangulation method. The evaluation of curriculum Implementation 2013 Biology subjects has been patting the Permendikbud No. 22 years 2016 on the standard of basic and secondary education process but still found gaps where: 1) on design planning in the preparation of materials/materials have not been sequential, analytical, related to the condition and actual; 2) on the Learning installation performance evaluation of biological teachers is already referring to the standards that are guided on the component aspects of planning, implementation, evaluation and no gaps; 3) The implementation process for the delivery of material has not been sequential, analytical, related to the condition and actual, as well as in preliminary activities, core activities and closing activities are not carried out optimally; 4) on learning outcomes have carried out an authentic assessment of the teaching learning process that is assessment Cognitive, affective, and psychomotor but the affective judgment only assesses prominent students. Recommendations need to be done to improve the design, process, and results so that in the implementation adjust the predefined standards.
\end{abstract}

Keywords: Curriculum 2013, Biology, Discrepancy

\section{Article Info}

Received date: 17 Mei $2019 \quad$ Revised date: 28 November $2019 \quad$ Accepted date: 17 Desember 2019

\section{PENDAHULUAN}

Perkembangan dunia pendidikan nasional mengalami transformasi dari masa ke masa untuk menghasilkan SDM yang terbaik. Pemerintah saat ini berusaha meningkatkan kualitas pendidikan nasional. Hal ini didasari oleh kebijakan pemerintah dalam UU Sisdiknas bahwa perlunya disusun standar nasional pendidikan salah satunya Standar Isi dimana bagian dari standar ini adalah Kurikulum.

$$
\text { Kurikulum adalah alat dalam }
$$

ketercapaian tujuan pendidikan sekalian panduan pelaksanaan proses pembelajaran disemua jenjang pendidikan dalam meningkatkan kualitas potensi anak didik. Seperti yang terdapat dalam Kemendikbud (2012: 2) bahwa kurikulum adalah basis yang paling penting untuk menghasilkan: 1) manusia berkualitas yang mampu dan proaktif menjawab tantangan zaman yang selalu berubah; 2) manusia terdidik yang beriman dan bertakwa terhadap Tuhan Yang Maha Esa, berakhlak mulia, sehat, berilmu, cakap, kreatif, mandiri; dan 3) warga negara yang demokratis dan bertanggung jawab. 
Saat ini beberapa sekolah salah satunya di SMAN 1 Waingapu mengimplementasikan Kurikulum 2013 yang merupakan jalan keluar untuk menyelesaikan permasalahan yang terjadi dalam sistem pendidikan dewasa ini. Maka dalam Permendikbud No. 22 tahun 2016 dalam proses pembelajaran diselenggarakan secara interaktif, inspiratif, menyenangkan, menantang, memotivasi peserta didik untuk berpartisipasi aktif, serta memberikan ruang yang cukup bagi prakarsa, kreativitas, dan kemandirian sesuai dengan bakat, minat, dan perkembangan fisik serta psikologis peserta didik agar menciptakan peserta didik yang bermutu. Kurikulum 2013 disebut juga kurikulum berbasis kompetensi dan karakter dan merupakan penyempurnaan dari KTSP. Dengan memakai Kurikulum 2013 ini dapat merubah mindset dalam pola mendidik di sekolah, Roza, A. dkk (2017:132).

Di dalam kurikulum sebuah sekolah semua bidang mata pelajaran terikat dengan sistem kurikulum yang berlaku saat itu. Demikian juga dengan mata pelajaran sains khususnya mata pelajaran biologi dimana dalam prakteknya harus mengikuti standar atau aturan kurikulum yang berlaku. Biologi merupakan salah satu cabang ilmu yang mengkaji segala sesuatu tentang kehidupan, Karmana (2007: 3). Dalam mengimplementasikan kurikulum 2013 mata pelajaran biologi diperlukan pemahaman yang mendalam dari para guru dalam keberhasilan penerapan kurikulum ini.

Implementasi kurikulum 2013 berbasis karakter dan kompetensi harus mengikutsertakan semua komponen, termasuk komponen-komponen yang ada dalam sistem pendidikan itu sendiri. Komponen-komponen tersebut antara lain kurikulum, rencana pembelajaran, proses pembelajaran, mekanisme penilaian, kualitas hubungan, pengelolaan pembelajaran, pengelolaan sekolah, pelaksanaan pengembangan diri peserta didik, pemberdayaan sarana prasarana, pembiayaan, serta etos kerja seluruh warga dan lingkungan sekolah, Djumali \& Erlina Wijayanti (2018: 31). Selanjutnya guru memiliki tanggung jawab serta kewajiban untuk melakukan upaya-upaya mendasar dalam berbagai bentuk inovasi pembelajaran agar pelaksanaan proses pembelajaran dapat mencapai kompetensi yang ditetapkan, sekaligus ikut mengantarkan anak-anak bangsa ini menjadi bangsa yang bermartabat dimata bangsanya maupun dimata internasional, Mukminan (2013: 1). Pendekatan dan strategi pembelajaran 2013 ini yang menonjol adalah pendekatan saintifik. Oleh sebab itu guru diharapkan dapat meningkatkan kinerja dan melaksanakan kebijakan dari pemerintah dengan mengetahui program, prinsip mekanisme serta cara dalam proses belajar mengajar terkait dengan penerapan Kurikulum 2013.

Berdasarkan informasi melalui wawancara dengan wakasek kurikulum bahwa perangkat pembelajaran yang disusun oleh guru-guru tertentu dalam pelaksanaannya belum mengacu pada prosedur kurikulum 2013 yang dituangkan dalam RPP di dalam kelas. Masih terjadi kesenjangan antara RPP yang sudah disusun dengan kenyataan di lapangan. Dimana kegiatan pendahuluan, kegiatan inti dan kegiatan penutup tidak dilakukan secara keseluruhan. Keadaan ini menimbulkan proses belajar dan mengajar dalam kelas kurang sesuai dengan target yang diinginkan dalam meningkatkan kualitas pembelajaran biologi yang adalah salah satu tolak ukur pencapaian tujuan pembelajaran. Selain itu, penilaian yang dibuat dalam perangkat pembelajaran adalah penilaian yang bersifat autentik yang mencakup ranah pengetahuan, sikap, dan psikomotor. Namun masih terjadi kesenjangan pada penilaian sikap tidak dilakukan secara komprehensif atau menyeluruh hanya dilakukan pada siswa yang menonjol saja.

Demikian halnya dengan penelitian dari Hari Setiadi (2016), dalam jurnal dengan judul 
Pelaksanaan Penilaian Pada Kurikulum 2013 ia menyarankan pemerintah bahwa dalam tahap pelaksanaan perlu dilakukan penyederhanaan pada pedoman penilaian Kurikulum 2013, dimana melakukan sosialisasi dan pelatihan penilaian kompetensi sikap, karena dari hasil temuan FGD ternyata sedikit sekali guru-guru yang melakukan penilaian kompetensi sikap baik dengan lembar observasi, lembar penilaian diri, penilaian antar teman, dan membuat jurnal. Banyak guru yang mengeluh kesulitan dalam melakukan penilaian sikap, terutama karena mereka tidak ada waktu yang cukup, dan terlalu banyak siswa yang harus dinilai.

Markle \& O’Banion (2014), dalam jurnal dengan judul Assessing Affective Factors to Improve Retention and Completion ia menemukan bahwa masih sangat sedikit guru yang melakukan penilaian afektif dengan baik di lapangan.

Berbeda dengan hasil penelitian Gusti (2017), dalam jurnal dengan judul Analisis Hasil Implementasi Kurikulum 2013 Dalam Aspek Sikap, Pengetahuan, dan Keterampilan Pada Mata Pelajaran Biologi SMA Di Kabupaten Sleman Yogyakarta, dia menemukan bahwa dari ketiga aspek tersebut dilakukan secara keseluruhan dan masuk dalam kategori "Baik" yang dapat menunjukkan adanya keberhasilan belajar siswa.

Achmad Sultoni (2016), dalam jurnal dengan judul Implementasi Kurikulum 2013 Bidang Studi Biologi dalam Mengembangkan Sikap Religius Siswa Di Madrasah Aliyah ia melakukan penilaian secara keseluruhan dimana: 1) pengembangan sikap religius dilakukan melalui rumusan tujuan pembelajaran dan penyampaian salam serta berdo'a diawal pembelajaran; 2) pelaksanaan pengembangan sikap religius dilakukan dengan cara menyampaikan salam dan do'a diawal pembelajaran, menghubungkan materi pembelajaran dengan ajaran islam, menyampaikan salam dan berdo'a kafaratul majlis diakhir pembelajaran, dan menegur siswa yang melanggar aturan islam. Namun masih ditemukan hambatan dalam penilaian karena tidak adanya panduan dalam menilai sikap religius siswa karena sekolah dan MGMP Biologi kota Malang juga tidak membuat panduan.

Umi Pratiwi dan Eka Farida (2015), dalam jurnal dengan judul Pengembangan Instrumen Penilaian HOTS Berbasis Kurikulum 2013 terhadap Sikap Disiplin ia mendapatkan hasil bahwa dalam penilaian sikap dilakukan secara keseluruhan khususnya pada sikap disiplin. Dimana pada proses pengembangan instrumen penilaian HOTS dan sikap disiplin dikatakan efektif/berhasil, karena mencapai kesuksesan instrumen penilaian dengan skor HOTS $73,3 \%$ dan sikap disiplin $90 \%$ dari skor total. Instrumen penilaian ini baik digunakan untuk siswa dengan keaktifan yang tinggi dan bekerja mandiri.

E Mulyasa, (2019), dalam jurnal dengan judul Implementasi Sistem Penilaian Kurikulum 2013 Di Sekolah Menengah Pertama ia menemukan bahwa penilaian sikap dilaksanakan dari mulai perencanaan, pelaksanaan dan tindak lanjut. Pada tahap perencanaan, guru-guru PABP dan guru-guru PPKn telah menyusun indikator pencapaian kompetensi dasar, yaitu indikator untuk mengukur keberhasilan pencapaian kompetensi. Sedangkan untuk mata pelajaran lainnya, guru-guru telah menentukan jenis sikap sosial dan sikap spiritual yang akan ditanamkan pada diri peserta didik. Penilaian sikap dilakukan dengan menggunakan teknik observasi, penilaian diri, dan penilaian antar teman. Hasil penilaian sikap dilakukan secara komprehensif dan dilaporkan kepada peserta didik dan orang tua dalam bentuk predikat $\mathrm{A}$ (amat baik), B (baik), dan C (kurang baik), disertai dengan deskripsinya.

Elwien Sulistya N. (2015), dalam jurnal dengan judul Implementasi Kurikulum 2013 Di Sekolah Dasar dia menemukan bahwa pada penilaian sikap dilakukan secara komprehensif 
pada setiap pembelajaran, selain itu juga penilaian sikap dilakukan oleh orang tua peserta didik yang membantu guru dalam penilaian sikap sehingga orang tua peserta didik dapat memberikan dukungan terhadap implementasi kurikulum 2013 dengan mengawasi dan membantu anak ketika belajar di rumah, hal ini orang tua dan anak didik merasa senang dengan adanya kurikulum 2013 karena adanya pembelajaran tematik integratif. Dengan demikian untuk ketercapaian kurikulum 2013 mata pelajaran biologi sangat dibutuhkan dukungan kinerja guru dan orang tua yang baik agar menghasilkan sumber daya manusia yang berkompetensi.

Untuk mengevaluasi implementasi kurikulum 2013 di SMAN 1 Waingapu khususnya pada mata pelajaran biologi, peneliti menggunakan model evaluasi kesenjangan oleh Malcolm Provus (1971) dalam bukunya tentang Discrepancy Evaluation. Komponen yang diperhatikan pada evaluasi model kesenjangan menurut Malcolm Provus adalah: 1) desain merupakan program yang didalamnya melibatkan siswa, staff, dan sumber daya yang ada untuk melakukan suatu aktivitas dalam mencapai tujuan; 2) instalasi merupakan rancangan yang menentukan sebuah program sebagai standar untuk mempertimbangkan langkah-langkah proses pelaksanaan program; 3) proses merupakan kegiatan memperoleh data tentang sejauh mana program telah berjalan dalam mencapai tujuan yang diharapkan; 4) produk merupakan hasil dari tujuan program yang telah dicapai; 5) analisis biaya dan manfaat merupakan suatu kegiatan membandingkan penggunaan biaya yang dikeluarkan dengan hasil yang dicapai (Rose \& Nyre, 1977: 15). Penelitian ini hanya menggunakan empat dari lima komponen evaluasi ini. Model ini mencari kesenjangan antara standar kurikulum 2013 mata pelajaran biologi yang baik dengan kenyataan yang terjadi dalam penerapan kurikulum 2013. Peneliti berharap bahwa model evaluasi kesenjangan ini dapat membantu menganalisis kelemahan-kelemahan dalam penerapan kurikulum 2013 mata pelajaran biologi di sekolah.

Berdasarkan latar belakang yang dijabarkan di atas, maka rumusan masalahnya adalah bagaimana desain, instalasi, proses, dan hasil Implementasi Kurikulum 2013 Mata Pelajaran Biologi Di SMAN 1 Waingapu? Tujuan penelitian ini adalah mengevaluasi desain, instalasi, proses, dan hasil Implementasi Kurikulum 2013 Mata Pelajaran Biologi Di SMAN 1 Waingapu.

Adapun manfaat dari penelitian ini adalah secara teoritis dapat bermanfaat untuk menambah referensi ilmu pengetahuan sebagai bahan kajian di bidang manajemen pendidikan khususnya dalam bidang evaluasi implementasi kurikulum 2013 di SMAN 1 Waingapu. Sedangkan manfaat praktis dapat memberikan gambaran yang bermanfaat bagi: a) Kepala sekolah yang nantinya digunakan sebagai bahan kajian atau rencana tindak lanjut dalam mengevaluasi implementasi kurikulum 2013 mata pelajaran biologi dimasa yang akan datang; b) Wakasek Kurikulum dan guru-guru dapat menambah wawasan dan digunakan sebagai acuan dalam memperbaiki implementasi kurikulum 2013 mata pelajaran biologi yang efektif dan efisien.

\section{METODE PENELITIAN}

Penelitian evaluatif yang dipakai pada penelitian ini. Jenisnya adalah evaluasi model kesenjangan (Discrepancy Evaluation Model) melalui komponen desain; instalasi; proses; hasil; analisis biaya dan manfaat. Penelitian ini dilakukan terbatas hanya sampai pada komponen hasil. Subjek penelitian ini Kepala sekolah, Wakasek Kurikulum, Guru-guru biologi, dan Siswa. Data dikumpulkan dengan teknik studi dokumen, observasi, dan wawancara. Analisis dalam penelitian ini dilakukan sejak sebelum dilapangan, setelah di lapangan, dan setelah selesai dilapangan. 
Teknik analisis data melalui koleksi data, reduksi data, display data, dan kesimpulan data. Triangulasi untuk menguji keobyaktifan data dilakukan dengan triangulasi sumber dan triangulasi metode untuk mengecek data dari nara sumber dengan hasil observasi dan studi dokumen.

\section{HASIL PENELITIAN DAN PEMBAHASAN}

Analisis data implementasi Kurikulum 2013 mata pelajaran biologi bahwa sekolah menggunakan silabus mengacu pada Permendikbud No. 22 tahun 2016 tentang Standar Proses Pendidikan Dasar dan Menengah sebagai pedoman penyusunan RPP. Aspek yang akan dievaluasi adalah tahap desain, instalasi, proses, dan hasil implementasi program. Pada masing-masing komponen tersebut akan diukur apakah ada kesenjangan antara kinerja program dengan standar/Juknis.

\section{Desain Pembelajaran}

Desain perencanaan Pembelajaran terdapat aspek-aspek yang dinilai yaitu Silabus, RPP dan Prinsip Penyusunan RPP. Dalam Silabus memiliki Standar/Juknis yaitu: a) Identitas mata pelajaran (khusus SMP/MTs/SMPLB/Paket B dan SMA/MA/SMALB/SMK/MAK/Paket C/Paket C Kejuruan); b) Identitas sekolah meliputi nama satuan pendidikaan dan kelas; c) Kompetensi inti, mengenai aspek sikap, pengetahuan, dan keterampilan; d) Kompetensi dasar yang mencakup sikap, pengetahuan, dan keterampilan; e) tema; f) Materi pokok; g) pembelajaran; h) Penilaian; i) alokasi waktu; dan j) sumber belajar, (Salinan Permendikbud No. 22 tahun 2016:5).

Rencana Pelaksanaan Pembelajaran (RPP) meliputi: identitas sekolah, identitas mata pelajaran, kelas/semester, materi pokok, alokasi waktu, tujuan pembelajaran, kompetensi dasar dan indikator pencapaian kompetensi, materi pembelajaran, metode pembelajaran, media pembelajaran, sumber belajar, langkah-langkah pembelajaran, serta penilaian hasil belajar. Prinsip penyusunan RPP meliputi: a) perbedaan individual peserta didik antara lain kemampuan awal, tingkat intelektual, bakat, potensi, minat, motivasi belajar, kemampuan sosial, emosi, gaya belajar, kebutuhan khusus, kecepatan belajar, latar belakang budaya, norma, nilai, dan/atau lingkungan peserta didik; b) partisipasi aktif peserta didik; c) Berpusat pada peserta didik untuk mendorong semangat belajar, motivasi, minat, krativitas, inisiatif, inspirasi, inovasi, dan kemandirian; d) pengembangan budaya membaca dan menulis, pemberian umpan balik (remidi, pengayaan dan penguatan); f) keterpaduan KD, materi, kegiatan belajar, indikator, penilaian, dan sumber belajar dalam satu keutuhan pengalaman belajar; g) pembelajaran tematik-terpadu; dan h) berbasis TI, (Salinan Permendikbud No. 22 tahun 2016:6-8).

Terkait indikator ini diperoleh hasil bahwa Kepala sekolah mengharuskan setiap guru untuk membuat suatu perencanaan dalam bentuk perangkat pembelajaran sebelum mengajar di dalam kelas. Semua guru biologi sudah membuat format silabus dan RPP yang sudah sesuai dengan standar/juknis tersebut. Dalam menyusun RPP juga dibuat mengacu pada prinsip pembuatan RPP dalam juknis.

Adapun hal lain dalam mendesain perencanaan kegiatan dalam pembelajaran meliputi empat indikator yaitu: 1) guru menyusun tujuan pembelajaran dalam Rencana Pelaksanaan Pembelajaran dengan mempertimbangkan kebutuhan siswa; 2) guru membuat materi secara berurutan, analitis, berhubungan dengan kondisi dan aktual; 3) guru merancangkan kegiatan pembelajaran yang benar; dan 4) guru menggunakan media pembelajaran berdasarkan materi dan strategi/cara dalam pembelajaran.

Pertama guru menyusun tujuan pembelajaran dalam Rencana Pelaksanaan Pembelajaran dengan mempertimbangkan 
kebutuhan siswa. Penyusunan RPP dilakukan secara mandiri dan secara bersama-sama yang kompak diantara para anggota tim melalui kegiatan MGMP, IHT (In House Training), Workshop, dan seminar. RPP yang sudah disusun oleh guru-guru sekolah di ujicobakan terlebih dahulu dalam kegiatan MGMP, apabila RPP ini layak digunakan baru akan diterapkan di lapangan namun ketika belum sesuai akan terus diusahakan mencari solusi agar bisa diterapkan. Guru mata pelajaran biologi membuat RPP untuk setiap kompetensi dasar yang digunakan untuk 1-2 pertemuan.

Kedua guru membuat materi secara berurutan, analitis, berhubungan dengan kondisi dan aktual. Berurutan berarti penyusunan bahan ajar dari yang mudah ke yang sulit, dari yang ringan kepada yang berat, dari yang konkrit kepada yang abstrak dan dari yang simpel kepada yang lebih rumit. Lalu analitis/logis berarti ada kesesuaian atau relevansi antara kedalaman materi yang akan disampaikan dengan kondisi atau kemampuan atau potensi siswa serta bakat, minat dan gaya belajarnya. Kemudian berhubungan dengan kondisi berarti penyusunan bahan ajar dibuat sesuai dengan situasi kehidupan dan perkembangan IPTEK (Sanjaya, 2010: 195). Yang terakhir adalah aktual dapat diartikan penyusunan bahan ajar tidak hanya mengacu pada buku-buku akan tetapi lebih kepada sumber-sumber ilmu pengetahuan lain sesuai keadaan saat ini dengan bentuk yang tidak terbatas (Majid, 2011: 60).

Idealnya semua poin di atas harus dipertimbangkan guru dalam setiap menyusun rencana pembelajaran. Akan tetapi sesuai apa yang peneliti temukan di lapangan, para guru dalam menyusun bahan ajar masih ada guru belum mepertimbangkan aspek poin-poin diatas secara menyeluruh. Ada guru yang memperhatikan aspek berurutan, analitis, berhubungan dengan kondisi dan hanya sebagian aktual saja. Ada yang analitis, berhubungan dengan kondisi, aktual dan hanya sebagian berurutan. Hal ini tentu menimbulkan kesenjangan antara teori atau standar yang ada dengan realitas yang terjadi di lapangan. Menurut peneliti memang tidak mudah menyusun materi dengan mempertimbangkan sudut pandang secara berurutan, analitis, berhubungan dengan kondisi dan aktual karena membutuhkan pemikiran mendalam serta pengetahuan yang komprehensif antara keadaan siswa, lingkungan dengan materi itu sendiri. Jadi wajar jika para subjek penelitian tidak secara menyeluruh mempertimbangkan aspek-aspek di atas untuk menyusun bahan ajar karena memang tidak mudah, akan tetapi kewajaran itu bukan berarti benar atau diperbolehkan guru tetap dituntut untuk bisa mempertimbangkan keempat aspek itu ketika menyusun bahan ajar meskipun belum seutuhnya baik.

Ketiga guru merancangkan kegiatan pembelajaran yang benar. Merancangkan kegiatan pembelajaran yang benar berarti pendidik sudah merancangkan suatu cara atau strategi agar pembelajaran menghasilkan nilainilai yang ada di dalam tujuan pembelajaran. Dengan pembelajaran yang efektif itu dapat mempermudah siswa dalam belajar atau menerima pelajaran. Semua subjek penelitian menyusun perencanaan dan strategi yang tidak jauh berbeda antara guru satu dengan yang lainnya dimana para guru memahami betul materi, merumuskan metode yang tepat, memformulasikan media yang ada, menyesuaikan metode dengan materi, merumuskan media pembelajaran yang sesuai, mengajak siswa berperan aktif dalam penyampaian materi, mengajak siswa merasakan, melihat dan mendengar secara langsung tentang isi bahan ajar yang diberikan, dan siswa diberi kesempatan memahami/membaca dan mendalami bahan ajar yang akan dipelajari diawal pertemuan.

Keempat guru menggunakan media pembelajaran berdasarkan materi dan strategi/cara dalam pembelajaran. Pada 
penelitian ini semua subjek penelitian telah memilih dan menggunakan media atau sumber belajar sebagai pendukung kegiatan pembelajaran. Pada pemilihan media atau sumber belajar ini disesuaikan dengan materi yang diajarkan. Hal ini bermaksud menyederhanakan jalannya pembelajaran, menaikkan ketepatan, mempertimbangkan kesesuaian bahan ajar dan target pembelajaran, serta mendukung dalam pemfokusan kegiatan belajar mengajar. Salah satu contoh guru 3 mengajak siswa ke luar sekolah yaitu pantai untuk mengamati secara kasat mata bagianbagian tumbuhan laut dan ciri-ciri tumbuhan laut dengan cara ini menimbulkan motivasi peserta didik dan dapat memudahkan siswa dalam menguasai bahan ajar. Artinya dalam konteks ini media atau sumber belajar tidak hanya dilakukan diseputaran sekolah namun juga di luar sekolah. Dalam mempersiapkan bahan ajar, sumber belajar, dan media pembelajaran guru-guru biologi juga menyiapkan materi berupa handout, power point yang disertai Video pembelajaran untuk menunjang pelaksanaan pembelajaran yang menyenangkan.
Dengan demikian dapat disimpulkan bahwa evaluasi desain perencanaan kurikulum 2013 mata pelajaran biologi adalah sekolah melaksanakan kegiatan MGMP dalam membuat silabus dan RPP sesuai prinsip pembuatan RPP yang mengacu pada juknis dan pelatihan-pelatihan lainnya untuk mempersamakan konsep dalam tujuan pembelajaran, jalannya/ proses, dan pengkondisian sumber daya dalam melaksanakan kegiatan pembelajaran untuk menggapai tujuan/ target program yang ditentukan. Walaupun masih ada kesenjangan dalam membuat materi secara berurutan, analitis, berhubungan dengan kondisi dan aktual.

\section{Instalasi Pembelajaran}

Dalam komponen instalasi terhadap evaluasi implementasi K 13 mata pelajaran biologi, mengacu pada standar proses pendidikan dasar dan menengah yang berasal dari Permendikbud No. 22 tahun 2016 yang termuat dalam Bab III, Bab IV dan Bab V. Hal tersebut dapat dilihat pada tabel kesiapan guru sebagai berikut:

Tabel 1. Kesiapan Guru

\begin{tabular}{|c|c|c|c|c|}
\hline No & $\begin{array}{l}\text { Komponen } \\
\text { Kesiapan } \\
\text { Guru }\end{array}$ & Juknis/ Standar & Kinerja & Keterangan \\
\hline 1 & Perencanaan & $\begin{array}{l}\text { Desain Pembelajaran: Silabus; RPP; } \\
\text { dan Prinsip penyusunan RPP }\end{array}$ & \multirow{3}{*}{$\begin{array}{l}\text { Wawancara Wakasek Kurikulum: } \\
\text { Pada ke tiga guru biologi disekolah ini } \\
\text { secara administrasi dalam persiapan } \\
\text { proses pembelajaran guru telah } \\
\text { membuat rancangan perencanaan, } \\
\text { pelaksanaan, dan evaluasi } \\
\text { pembelajaran yang sesuai dengan } \\
\text { juknis atau standar yang ditetapkan }\end{array}$} & \multirow{3}{*}{$\begin{array}{c}\text { Tidak ada } \\
\text { Kesenjangan }\end{array}$} \\
\hline 2 & Pelaksanaan & $\begin{array}{l}\text { Pelaksanaan Pembelajaran meliputi } \\
\text { kegiatan: pendahuluan; inti; dan } \\
\text { penutup }\end{array}$ & & \\
\hline 3 & Evaluasi & $\begin{array}{l}\text { Evaluasi menggunakan penilaian } \\
\text { otentik dengan metode dan alat tes } \\
\text { lisan; tertulis }\end{array}$ & & \\
\hline
\end{tabular}

Sumber: Permendikbud No. 22 tahun 2016 dan Data Penelitian

Berdasarkan tabel 1. di atas, dapat dijelaskan bahwa hasil yang didapat dari wakasek kurikulum melihat pada setiap guru biologi secara administrasi telah membuat rancangan perencanaan, pelaksanaan, dan evaluasi dalam menjalankan kinerja proses belajar mengajar. Dengan demikian bahwa tahap instalasi evaluasi kinerja guru biologi sudah mengacu pada standar proses pendidikan dasar dan menengah yang berpedoman pada 
aspek komponen perencanaan, pelaksanaan, dan evaluasi dan sudah sesuai juknis yang digunakan serta tidak ada kesenjangan.

Proses Pelaksanaan Pembelajaran

Tabel 2. Proses Pelaksanaan Pembelajaran

\begin{tabular}{|c|c|c|c|c|c|c|}
\hline \multirow[t]{2}{*}{ Aspek Evaluasi } & \multirow{2}{*}{\multicolumn{2}{|c|}{ Standar/Juknis }} & \multicolumn{3}{|c|}{ Kinerja } & \multirow[t]{2}{*}{ Keterangan } \\
\hline & & & Guru 1 & Guru 2 & Guru 3 & \\
\hline \multirow[t]{5}{*}{$\begin{array}{l}\text { 1. Kegiatan } \\
\text { Pendahuluan }\end{array}$} & a. & $\begin{array}{l}\text { menyiapkan peserta } \\
\text { didik secara psikis } \\
\text { dan fisik untuk } \\
\text { mengikuti proses } \\
\text { pembelajaran; }\end{array}$ & $\begin{array}{l}\text { Pada } \\
\text { pertemuan } \\
\text { tertentu tidak } \\
\text { mempersiapkan } \\
\text { peserta didik } \\
\text { secara psikis } \\
\text { dalam } \\
\text { mengikuti } \\
\text { pembelajaran } \\
\text { seperti kegiatan } \\
\text { doa, salam dan } \\
\text { apersepsi tidak } \\
\text { dilakukan } \\
\text { namun } \\
\text { langsung pada } \\
\text { kegiatan } \\
\text { penyampaian } \\
\text { tujuan } \\
\text { pembelajaran. }\end{array}$ & $\begin{array}{l}\text { Pada } \\
\text { pertemuan } \\
\text { tertentu tidak } \\
\text { mempersiapkan } \\
\text { peserta didik } \\
\text { secara psikis } \\
\text { dalam } \\
\text { mengikuti } \\
\text { pembelajaran } \\
\text { seperti kegiatan } \\
\text { doa, salam dan } \\
\text { apersepsi tidak } \\
\text { dilakukan } \\
\text { namun } \\
\text { langsung pada } \\
\text { kegiatan } \\
\text { penyampaian } \\
\text { tujuan } \\
\text { pembelajaran }\end{array}$ & $\begin{array}{l}\text { Dalam setiap } \\
\text { pertemuan } \\
\text { selalu } \\
\text { mempersiapkan } \\
\text { siswa baik } \\
\text { secara psikis } \\
\text { maupun fisik } \\
\text { dalam } \\
\text { pembelajaran }\end{array}$ & $\begin{array}{l}\text { Guru } 1 \text { dan } \\
\text { 2: Ada } \\
\text { kesenjangan }\end{array}$ \\
\hline & b. & $\begin{array}{l}\text { memberi motivasi } \\
\text { belajar peserta didik } \\
\text { secara kontekstual } \\
\text { sesuai manfaat dan } \\
\text { aplikasi materi ajar } \\
\text { dalam kehidupan } \\
\text { sehari-hari, dengan } \\
\text { memberikan contoh } \\
\text { dan perbandingan } \\
\text { lokal, nasional dan } \\
\text { internasional, serta } \\
\text { disesuaikan dengan } \\
\text { karakteristik dan } \\
\text { jenjang peserta didik; }\end{array}$ & $\begin{array}{l}\text { Dalam setiap } \\
\text { pertemuan } \\
\text { melakukan } \\
\text { motivasi } \\
\text { belajar } \\
\text { terhadap } \\
\text { peserta didik }\end{array}$ & $\begin{array}{l}\text { Dalam setiap } \\
\text { pertemuan } \\
\text { dilakukan } \\
\text { motivasi } \\
\text { belajar pada } \\
\text { peserta didik }\end{array}$ & $\begin{array}{l}\text { Dalam setiap } \\
\text { pertemuan } \\
\text { melakukan } \\
\text { motivasi } \\
\text { belajar pada } \\
\text { peserta didik }\end{array}$ & $\begin{array}{c}\text { Tidak ada } \\
\text { kesenjangan }\end{array}$ \\
\hline & c. & $\begin{array}{l}\text { mengajukan } \\
\text { pertanyaan- } \\
\text { pertanyaan yang } \\
\text { mengaitkan } \\
\text { pengetahuan } \\
\text { sebelumnya dengan } \\
\text { materi yang akan } \\
\text { dipelajari; }\end{array}$ & $\begin{array}{l}\text { Setiap } \\
\text { pertemuan } \\
\text { selalu } \\
\text { memberikan } \\
\text { pertanyaan- } \\
\text { pertanyaan } \\
\text { baik di awal, } \\
\text { pertengahan } \\
\text { PBM } \\
\end{array}$ & $\begin{array}{l}\text { Setiap } \\
\text { pertemuan } \\
\text { selalu } \\
\text { memberikan } \\
\text { pertanyaan- } \\
\text { pertanyaan } \\
\text { dalam PBM }\end{array}$ & $\begin{array}{l}\text { Setiap } \\
\text { pertemuan } \\
\text { selalu diberi } \\
\text { pertanyaan- } \\
\text { pertanyaan } \\
\text { dalam PBM }\end{array}$ & $\begin{array}{c}\text { Tidak ada } \\
\text { kesenjangan }\end{array}$ \\
\hline & d. & $\begin{array}{l}\text { menjelaskan tujuan } \\
\text { pembelajaran atau } \\
\text { kompetensi dasar } \\
\text { yang akan dicapai; } \\
\text { dan }\end{array}$ & $\begin{array}{l}\text { Setiap } \\
\text { pertemuan } \\
\text { selalu } \\
\text { menyampaikan } \\
\text { tujuan } \\
\text { pembelajaran }\end{array}$ & $\begin{array}{l}\text { Tujuan } \\
\text { pembelajaran } \\
\text { pada setiap } \\
\text { pertemuan } \\
\text { selalu } \\
\text { disampaikan }\end{array}$ & $\begin{array}{l}\text { Setiap } \\
\text { pertemuan } \\
\text { tujuan } \\
\text { pembelajaran } \\
\text { selalu } \\
\text { disampaikan }\end{array}$ & $\begin{array}{c}\text { Tidak ada } \\
\text { kesenjangan }\end{array}$ \\
\hline & e. & $\begin{array}{l}\text { menyampaikan } \\
\text { cakupan materi dan } \\
\text { penjelasan uraian } \\
\text { kegiatan sesuai } \\
\text { silabus. }\end{array}$ & $\begin{array}{l}\text { Selalu } \\
\text { menyampaikan } \\
\text { cakupan materi } \\
\text { dan penjelasan } \\
\text { materi secara }\end{array}$ & $\begin{array}{l}\text { Selalu } \\
\text { menyampaikan } \\
\text { materi } \\
\text { pengantar }\end{array}$ & $\begin{array}{l}\text { Selalu } \\
\text { menyampaikan } \\
\text { materi } \\
\text { pengantar dan } \\
\text { dilakukan }\end{array}$ & $\begin{array}{c}\text { Tidak ada } \\
\text { kesenjangan }\end{array}$ \\
\hline
\end{tabular}




\begin{tabular}{|c|c|c|c|c|c|}
\hline \multirow[t]{2}{*}{ Aspek Evaluasi } & \multirow[t]{2}{*}{ Standar/Juknis } & \multicolumn{3}{|c|}{ Kinerja } & \multirow{2}{*}{ Keterangan } \\
\hline & & Guru 1 & Guru 2 & Guru 3 & \\
\hline & & $\begin{array}{l}\text { umum dan } \\
\text { singkat } \\
\text { selebihnya } \\
\text { dibagi dalam } \\
\text { kelompok dan } \\
\text { siswa } \\
\text { membedah } \\
\text { materi dengan } \\
\text { mengambil dari } \\
\text { berbagai } \\
\text { sumber }\end{array}$ & & $\begin{array}{l}\text { diskusi } \\
\text { kelompok }\end{array}$ & \\
\hline \multirow[t]{3}{*}{$\begin{array}{l}\text { 2. Kegiatan } \\
\text { Inti }\end{array}$} & $\begin{array}{l}\text { a. Sikap : proses afeksi } \\
\text { mulai dari menerima, } \\
\text { menjalankan, } \\
\text { menghargai, } \\
\text { menghayati, hingga } \\
\text { mengamalkan }\end{array}$ & $\begin{array}{l}\text { Pada setiap } \\
\text { pertemuan } \\
\text { selalu } \\
\text { dilaksanakan } \\
\text { proses afeksi } \\
\text { baik dari awal } \\
\text { sampai akhir } \\
\text { pertemuan. }\end{array}$ & $\begin{array}{l}\text { Proses afeksi } \\
\text { pada setiap } \\
\text { pertemuan } \\
\text { selalu } \\
\text { dilaksanakan } \\
\text { baik dari awal } \\
\text { sampai akhir } \\
\text { pertemuan. }\end{array}$ & $\begin{array}{l}\text { Pada setiap } \\
\text { pertemuan baik } \\
\text { dari awal } \\
\text { sampai akhir } \\
\text { pertemuan } \\
\text { selalu } \\
\text { dilaksanakan } \\
\text { proses afeksi }\end{array}$ & $\begin{array}{c}\text { Tidak ada } \\
\text { kesenjangan }\end{array}$ \\
\hline & $\begin{array}{l}\text { b. Pengetahuan: melalui } \\
\text { aktivitas mengetahui, } \\
\text { memahami, } \\
\text { menerapkan, } \\
\text { menganalisis, } \\
\text { mengevaluasi, hingga } \\
\text { mencipta }\end{array}$ & $\begin{array}{l}\text { Selalu dilakuan } \\
\text { dan hal } \\
\text { menciptakan } \\
\text { pada } \\
\text { pertemuan } \\
\text { berikutnya }\end{array}$ & $\begin{array}{l}\text { Selalu dilakuan } \\
\text { sampai waktu } \\
\text { pertemuan } \\
\text { yang sudah } \\
\text { ditentukan di } \\
\text { RPP. }\end{array}$ & Selalu dilakuan & $\begin{array}{c}\text { Tidak ada } \\
\text { kesenjangan }\end{array}$ \\
\hline & $\begin{array}{ll}\text { c. } & \text { Keterampilan: } \\
\text { melalui kegiatan } \\
\text { mengamati, } \\
\text { menanya, mencoba, } \\
\text { menalar, menyaji, } \\
\text { dan mencipta }\end{array}$ & $\begin{array}{l}\text { Pada kegiatan } \\
\text { ini tidak } \\
\text { dilakukan } \\
\text { secara } \\
\text { keseluruhan } \\
\text { pada } \\
\text { pertemuan } \\
\text { tertentu hanya } \\
\text { dilakukan } \\
\text { kegiatan } \\
\text { mengamati dan } \\
\text { langsung diberi } \\
\text { instruksi } \\
\text { kepada siswa } \\
\text { untuk } \\
\text { meringkas } \\
\text { materi } \\
\text { sehingga } \\
\text { kegiatan } \\
\text { menanya, } \\
\text { mencoba, } \\
\text { menalar, } \\
\text { menyaji dan } \\
\text { mencipta tidak } \\
\text { dilakukan }\end{array}$ & $\begin{array}{l}\text { Pada setiap } \\
\text { pertemuan } \\
\text { dilakukan } \\
\text { kegiatan } \\
\text { mengamati, } \\
\text { menanya, } \\
\text { mencoba, } \\
\text { menalar, } \\
\text { menyaji dan } \\
\text { mencipta selalu } \\
\text { dilakukan } \\
\text { meskipin tidak } \\
\text { selesai dalam } \\
\text { satu kali } \\
\text { pertemuan }\end{array}$ & $\begin{array}{l}\text { Pada setiap } \\
\text { pertemuan } \\
\text { selalu } \\
\text { dilakukan } \\
\text { kegiatan } \\
\text { mengamati, } \\
\text { menanya, } \\
\text { mencoba, } \\
\text { menalar, } \\
\text { menyaji dan } \\
\text { mencipta } \\
\text { namun } \\
\text { terkadang } \\
\text { selesai dalam } 3 \\
\text { kali pertemuan }\end{array}$ & $\begin{array}{l}\text { Guru 1: ada } \\
\text { kesenjangan }\end{array}$ \\
\hline $\begin{array}{l}\text { 3. } \\
\text { Kegiatan } \\
\text { Penutup }\end{array}$ & $\begin{array}{ll}\text { a. } & \text { seluruh rangkaian } \\
\text { aktivitas } \\
\text { pembelajaran dan } \\
\text { hasil-hasil yang } \\
\text { diperoleh untuk } \\
\text { selanjutnya secara } \\
\text { bersama menemukan } \\
\text { manfaat langsung } \\
\text { maupun tidak }\end{array}$ & $\begin{array}{l}\text { Pada akhir } \\
\text { pembelajaran } \\
\text { baik secara } \\
\text { langsung } \\
\text { maupun secara } \\
\text { tidak langsung } \\
\text { dilakukan } \\
\text { penarikan } \\
\text { kesimpulan }\end{array}$ & $\begin{array}{l}\text { Selalu } \\
\text { dilakukan } \\
\text { penutupan } \\
\text { dalam hal } \\
\text { membuat } \\
\text { kesimpulan } \\
\text { dengan } \\
\text { berbagai cara } \\
\text { untuk }\end{array}$ & $\begin{array}{l}\text { Selalu } \\
\text { dilakukan } \\
\text { penarikan } \\
\text { kesimpulan } \\
\text { secara bersama } \\
\text { baik guru } \\
\text { maupun siswa }\end{array}$ & $\begin{array}{c}\text { Tidak ada } \\
\text { kesenjangan }\end{array}$ \\
\hline
\end{tabular}




\begin{tabular}{|c|c|c|c|c|c|c|}
\hline \multirow[t]{2}{*}{ Aspek Evaluasi } & \multirow{2}{*}{\multicolumn{2}{|c|}{ Standar/Juknis }} & \multicolumn{3}{|c|}{ Kinerja } & \multirow{2}{*}{ Keterangan } \\
\hline & & & Guru 1 & Guru 2 & Guru 3 & \\
\hline & & $\begin{array}{l}\text { langsung dari hasil } \\
\text { pembelajaran yang } \\
\text { telah berlangsung; }\end{array}$ & $\begin{array}{l}\text { pada materi } \\
\text { yang diajarkan } \\
\text { untuk } \\
\text { menemukan } \\
\text { manfaat dari } \\
\text { materi tersebut } \\
\text { dalam } \\
\text { kehidupan } \\
\text { sehari-hari }\end{array}$ & $\begin{array}{l}\text { menemukan } \\
\text { manfaat pada } \\
\text { materi yang } \\
\text { diajar }\end{array}$ & & \\
\hline & b. & $\begin{array}{l}\text { memberikan umpan } \\
\text { balik terhadap proses } \\
\text { dan hasil } \\
\text { pembelajaran; }\end{array}$ & $\begin{array}{l}\text { Pada } \\
\text { pertemuan } \\
\text { tertentu tidak } \\
\text { dilakukan } \\
\text { umpan balik } \\
\text { atau evaluasi }\end{array}$ & $\begin{array}{l}\text { Pada } \\
\text { pertemuan } \\
\text { tertentu tidak } \\
\text { dilakukan } \\
\text { umpan balik } \\
\text { atau evaluasi }\end{array}$ & $\begin{array}{l}\text { Pada } \\
\text { peretmuan } \\
\text { tertentu tidak } \\
\text { dilakukan } \\
\text { umpan balik } \\
\text { atau evaluasi }\end{array}$ & $\begin{array}{c}\text { Ada } \\
\text { Kesenjangan }\end{array}$ \\
\hline & c. & $\begin{array}{l}\text { melakukan kegiatan } \\
\text { tindak lanjut dalam } \\
\text { bentuk pemberian } \\
\text { tugas, baik tugas } \\
\text { individual maupun } \\
\text { kelompok; dan }\end{array}$ & $\begin{array}{l}\text { Pada setiap } \\
\text { pertemuan } \\
\text { selalu diberi } \\
\text { tugas baik } \\
\text { individu } \\
\text { maupun } \\
\text { kelompok }\end{array}$ & $\begin{array}{l}\text { Pada setiap } \\
\text { pertemuan } \\
\text { selalu diberi } \\
\text { tugas baik } \\
\text { individu } \\
\text { maupun } \\
\text { kelompok }\end{array}$ & $\begin{array}{l}\text { Pada setiap } \\
\text { pertemuan } \\
\text { selalu diberi } \\
\text { tugas baik } \\
\text { individu } \\
\text { maupun } \\
\text { kelompok }\end{array}$ & $\begin{array}{c}\text { Tidak ada } \\
\text { kesenjangan }\end{array}$ \\
\hline & $\mathrm{d}$. & $\begin{array}{l}\text { menginformasikan } \\
\text { rencana kegiatan } \\
\text { pembelajaran untuk } \\
\text { pertemuan berikutnya }\end{array}$ & $\begin{array}{l}\text { Selalu diberi } \\
\text { informasi } \\
\text { untuk kegiatan } \\
\text { pembelajaran } \\
\text { berikutnya }\end{array}$ & $\begin{array}{l}\text { Selalu diberi } \\
\text { informasi } \\
\text { untuk kegiatan } \\
\text { pembelajaran } \\
\text { berikutnya }\end{array}$ & $\begin{array}{l}\text { Selalu diberi } \\
\text { informasi } \\
\text { untuk kegiatan } \\
\text { pembelajaran } \\
\text { berikutnya }\end{array}$ & $\begin{array}{c}\text { Tidak ada } \\
\text { kesenjangan }\end{array}$ \\
\hline
\end{tabular}

Sumber : Permendikbud No. 22 Tahun 2016 dan Data Penelitian

Pada penelitian ini dalam pelaksanaan pembelajaran peneliti melihat bahwa guru-guru menerapkan pendekatan saintifik dalam langkah-langkah kegiatan pembelajaran, terutama pada kegiatan inti pembelajaran. Kegiatan utama dalam pendekatan saintifik yang dilakukan yaitu mengamati, menanya, mencoba, mengasosiasi, dan menyampaikan/ mempresentasikan. Hal ini sama dengan Fadlillah (2014: 175) mendefinisikan pendekatan saintifik yang digunakan dalam pembelajaran tersebut dilakukan melalui proses ilmiah yaitu proses mengamati, menanya, mencoba, mengasosiasi dan mengkomunikasikan. Pembelajaran ini yang dilakukan adalah student center sedangkan guru hanyalah sebagai fasilitator dan salah satu sumber belajar bagi siswa. Kegiatan pembelajaran seperti ini dapat membentuk sikap, keterampilan, dan pengetahuan siswa secara maksimal.
Pelaksanaan pembelajaran di sekolah dikelompokkan menjadi tiga kegiatan besar ialah kegiatan pendahuluan, kegiatan inti, dan kegiatan penutup. Pada kegiatan ini siswa diberi kebebasan berpikir memahami problem, mengemukakan berbagai gagasan yang leluasa dan jelas. Pekerjaan pendidik dalam proses belajar mengajar ialah memimpin dan mengarahkan peserta didik berpikir tingkat tinggi, kritis dan berkreatif dalam menyelesaikan problem, selain itu siswa diminta aktif dan kreatif untuk mencari literatur materi secara luas yang di dapat dari sekolah, internet, masyarakat, dan lingkungan sekitar.

Indikator pertama adalah guru mengawali proses belajar mengajar dengan benar. Untuk mengawali proses belajar mengajar tersebut, tiga guru sebagai subjek penelitian memulai pelajaran diawali dengan salam pembuka, doa, apersepsi, inti dari kegiatan pembuka dalam pelajaran adalah apersepsi. Apersepsi merupakan kegiatan awal 
untuk menyamakan persepsi siswa tentang pelajaran yang hendak diajari, kemudian menghubungkan bahan ajar yang akan disampaikan dengan bahan ajar yang telah diajari atau mengaitkan bahan ajar dengan pengalaman-pengalaman guru atau orang lain yang telah dilakukan. Kegiatan ini agar siswa lebih tertarik dan menimbulkan rasa ingin tahu tentang materi yang akan diajarkan. Dari penjelasan di atas dapat dilihat dari kegiatan pendahuluan dengan strategi yang dilakukan: 1) pendidik selalu menanyakan kesiapan peserta didik untuk berpartisipasi dalam pembelajaran dan menciptakan suasana kelas yang memuaskan, 2) mereview bahan ajar yang sudah dipelajari keterkaitan dengan bahan ajar yang hendak disampaikan, 3) memberikan informasi mengenai pembelajaran yang akan dilaksanakan, 4) memberikan apersepsi untuk menumbuhkan rasa keingintahuan siswa. Untuk menarik minat dan menggugah kesadaran siswa, terkadang guru menayangkan video yang sesuai dengan tema pembelajaran yang akan disampaikan. Pada kegiatan pendahuluan ini masih ada kesenjangan dimana terkadang pada pertemuan tertentu seperti salam, doa, apersepsi tidak semua dilaksanakan oleh guru 1 dan guru 2 sebagai subjek penelitian karena dengan berbagai latar belakang masalah yang dialami. Hal ini terjadi kesenjangan bahwa RPP yang sudah disusun tidak sesuai dengan penerapannya didalam kelas.

Berbeda dengan penelitian relevan yang dilakukan oleh Sultoni pada tahun 2016 di SMA Negeri 3 Malang bahwa hasil penelitiannya menyatakan bahwa dalam kegiatan pendahuluan justru selalu dilaksanakan dan menonjolkan sikap religius siswa melalui aktifitas menyampaikan salam dan berdoa sangat penting. Hal ini dapat mencapai KI 1 dan KI 2 dalam kompetensi sikap religius sedangkan apersepsi siswa untuk mengingat materi pada pertemuan sebelumnya dan yang merangsang siswa untuk mengikuti materi pembelajaran yang akan diajarkan.
Pada kegiatan inti dalam langkahlangkah kegiatan pembelajaran, guru sudah menerapkan pendekatan saintifik yaitu mengamati, menanya, mencoba, mengasosiasi, dan mengkomunikasikan. Dengan pendekatan saintifik yang digunakan tersebut sama dengan penelitian relevan yang dilakukan oleh Bintari pada tahun 2014 di SMA Negeri 2 Amlapura khususnya pada pembelajaran bahasa indonesia bahwa pada proses pelaksanaan pembelajaran, guru menggunakan pendekatan saintifik dalam kegiatan inti yaitu langkah-langkah pembelajaran menggunakan kegiatan mengamati; menanya; mencoba; mengasosiasi; dan mengkomunikasikan. Walaupun kelima pendekatan tersebut secara keseluruhan tidak dilaksanakan dalam satu kali pertemuan. Dalam kegiatan inti yang dilakukan oleh guru 1 sebagai salah satu subjek penelitian di SMAN 1 Waingapu masih terjadi kesenjangan dimana guru 1 terkadang pada pertemuan tertentu belum sepenuhnya melaksanakan kelima pendekatan tersebut dimana hanya sampai pada pendekatan pertama yaitu mengamati setelah mengamati langsung diberikan instruksi untuk meringkas materi tersebut dengan menggunakan buku paket yang telah dibagi. Sehingga kegiatan menanya sampai pada mengkomunikasikan tidak

dilakukan. Hal ini tentu terjadi kesenjangan bahwa tidak mengacu dan bertentangan dengan pelaksanaan dalam pembelajaran berdasarkan Permendikbud No. 22 tahun 2016.

Indikator kedua adalah guru menguasai materi pelajaran/ materi praktikum. Guru yang menguasai materi pelajaran/ materi praktikum dapat mendukung kelancaran dan keberhasilan serta efektif dalam pembelajaran di kelas. Pada indikator ini peneliti menemukan bahwa semua subjek penelitian memakai berbagai macam cara untuk berusaha menguasai materi yang diajarkan dan dapat menyesuaikan dengan perkembangan zaman, agar aktivitas dalam belajar mengajar bisa dilaksanakan dengan 
benar dan dapat diterima oleh siswa. Walau pada salah satu guru tidak menguasai beberapa istilah latin dalam mata pelajaran biologi namun hal tersebut diatasi dengan belajar bersama dan memanfaatkan internet gratis dari sekolah.

Indikator ketiga adalah menerapkan pendekatan atau strategi pembelajaran yang efektif. Pada penelitian ini semua subjek teliti telah berusaha menggunakan berbagai macam strategi saat menyampaikan mata pelajaran kepada siswa, memilih strategi pembelajaran siswa dapat lebih mudah menerima materi. Makin banyak metode makin lebih efektif dan menarik dalam pembelajaran. Tentu beda materi terkadang juga beda metodenya. Hasil penelitian ini peneliti memperoleh data bahwa metode guru yang dipakai kurang menantang sehingga kurang menyenangkan siswa, dan terkadang pada materi tertentu siswa jenuh dalam mengikuti proses pembelajaran di kelas. Metode yang paling banyak digunakan adalah eksperimen, diskusi, tanya jawab, penyelesaian masalah dan penugasan, harapan dari siswa bahwa metode yang digunakan perlu di gunakan metode games, keteladanan, dan metode lainnya dalam $\mathrm{K} \quad 13$ sehingga pembelajaran dapat menyenangkan siswa.

Indikator keempat adalah pendidik menggunakan alat peraga dalam belajar mengajar. Hasil penelitian menunjukkan bahwa seluruh subjek penelitian telah memanfaatkan sumber belajar atau media pembelajaran. Para pendidik diharapkan dapat lebih mengembangkan kreatifitasnya dan dapat berinovasi dalam mencoba apakah sumber belajar atau media yang digunakan memberikan pengaruh positif kepada siswa atau tidak, jika berpengaruh positif berarti media yang digunakan tepat. Media pembelajaran yang dipakai adalah dari buku, gambar, video, internet, lingkungan sekitar sekolah, dan lingkungan luar sekolah salah satu contoh tumbuhan yang ada di pesisir pantai.
Indikator kelima adalah memotivasi mengikutsertakan peserta didik dalam kegiatan belajar mengajar. Indikator ini terjadinya sistem pembelajaran dua arah atau siswa lebih ditekankan untuk terlibat aktif dalam proses belajar mengajar, guru alat penyedia atau penunjang. Pada penelitian ini, semua subjek teliti telah melakukan kegiatan pembelajaran dengan mengikutsertakan siswa untuk memberikan pelajaran, menanggapi serta menyangga opini guru atau teman yang lain terhadap suatu permasalahan. Akan tetapi masih ada kelas tertentu yang siswanya kurang aktif. Permasalahan ini tentu menurut peneliti guru harus berusaha untuk membuat formulasi terbaik agar semua siswa dapat aktif dan berantusias positif dalam kelas. Ada hal yang menarik bahwa guru sudah berusaha untuk merubah sistem pembelajaran dua arah dimana melibatkan siswa untuk aktif, kreatif dan mencari literatur materi secara luas yang didapat dari sekolah, masyarakat, dan lingkungan sekitar rumah. Misalnya diberi tugas membuat laporan hasil observasi, siswa diminta untuk mengamati dan melakukan observasi keadaan sekitar dan mencari sumber disekitar terkait materi yang diajarkan. Dengan demikian siswa dengan sendirinya mengerjakan tugas tersebut secara mandiri dan bekerja sama dengan teman-temannya hal ini dapat membuat siswa aktif.

Indikator keenam adalah pendidik memakai kata-kata yang tepat dan benar dalam belajar mengajar. Hasil penelitian menunjukkan bahwa semua pendidik sudah memakai kata-kata yang baku baik dan benar dalam kegiatan pembelajaran di dalam kelas maupun di laboratorium.

Indikator ketujuh adalah guru mengakhiri pembelajaran atau kegiatan praktikum yang efektif. Kegiatan akhir adalah kegiatan menutup pelajaran, melakukan penilaian hasil belajar siswa dan tindak lanjut. Sama halnya dengan penelitian relevan yang diteliti oleh Sultoni bahwa pada kegiatan 
penutup pendidik melaksanakan umpan balik secara verbal terhadap peserta didik dan melakukan tindak lanjut dalam hal memberikan penugasan kepada siswa tentang bahan ajar yang hendak dipelajari pada tatap muka/ pertemuan selanjutnya. Proses pembelajaran efektif adalah guru memberikan penekanan dan menyimpulkan atau membuat rangkuman atas pelajaran yang telah disampaikan, memberikan motivasi kepada siswa serta pesan-pesan kebaikan dan memberikan evaluasi tes pada akhir pelajaran. Selain itu dalam melakukan evaluasi, para guru secara umum sudah menerapkan penilaian autentik meliputi ranah afektif, kognitif, dan psikomotor. Namun masih terjadi kesenjangan bahwa pada pertemuan tertentu guru tidak melakukan salah satu dari kegiatan penutup yaitu evaluasi karena alasan tertentu, artinya peserta didik diberikan pekerjaan rumah/tugas sebagai keberlanjutan dalam aktivitas belajar mengajar. Padahal kegiatan penilaian ini sangat perlu diadakan untuk mengecek ketercapaian KD dalam pertemuan itu. Dengan demikian evaluasi proses pelaksanaan implementasi kurikulum 2013 belum sesuai dengan standar pelaksanaan proses belajar mengajar berdasarkan Permendikbud No. 22 tahun 2016.

\section{Hasil Pembelajaran}

Berdasarkan standar yang ditetapkan dalam penilaian dalam proses belajar mengajar memakai pendekatan penilaian autentik yang mencakup ranah sikap, keterampilan, dan psikomotor. Hasil penilaian autentik ini digunakan untuk program perbaikan, pengayaan pembelajaran. Evaluasi ini memakai alat: halaman pengamatan, penilaian sejawat, merekam, catatan anekdot, dan refleksi yang dilakukam baik secara lisan maupun tertulis. Hasil penilaian akhir yang didapat dari penggabungan penilaian proses dan penilaian hasil belajar mengajar.

Evaluasi yang dilaksanakan di sekolah sudah mengikuti standar yang ada yaitu penilaian autentik meliputi afektif, kognitif dan psikomotor artinya menilai perkembangan belajar siswa, mulai dari awal proses hingga keluaran pembelajaran. Penilaian afektif mencakup pengamatan, evaluasi sendiri, evaluasi terhadap teman sejawat, dan artikel. Penilaian kognitif mencakup penilaian verbal dan non verbal, dan tes pemberian tugas atau penugasan. Penilaian keterampilan meliputi unjuk kerja, proyek, dan partofolio, serta rubrik penilaian masing-masing. Penilaian teknik ini diutamakan pada rata-rata dari ke-3 aspek tersebut secara komprehensif yang mengacu pada target yang ditetapkan dalam proses belajar mengajar sehingga sangat membantu ketuntasan siswa. Keberhasilan siswa dilihat dari ketercapaian kriteria ketuntasan minimal (KKM). Setelah melakukan telaah hasil belajar langkah selanjutnya dilakukan program penguatan/tindak lanjut yang berpedoman pada hasil penataan ketercapaian kompetensi siswa lewat menganalisis hasil evaluasi/penilaian. Guru merancang program penguatan/tindak lanjut, ini dilakukan agar siswa yang sudah tuntas mencapai serta melampaui KKM diberikan program pengayaan dan belum tuntas dibawah KKM dengan mengikuti program remidi. Standar KKM Sekolah ini yaitu KKM kelas $X=70$ sedangkan kelas $\mathrm{XII}=74$. Namun masih terdapat kesenjangan dalam penilaian ini terutama pada penilaian sikap terkadang pada pertemuan tertentu Guru 2 melakukan penilaian hanya pada siswa yang menonjol saja tidak dilakukan pada keseluruhan peserta didik. Hal ini dikarenakan guru tersebut mengalami keterbatasan waktu dan mengalami kesusahan dalam penilaian tersebut dengan jumlah siswa yang banyak. Sama halnya dengan penelitian yang dilakukan oleh Heri Retnawati (2015), dalam jurnal dengan judul Hambatan Guru Matematika Sekolah Menengah Pertama Dalam Menerapkan Kurikulum Baru ia mendapatkan hasil bahwa semua guru yang menjadi responden mengeluhkan bahwa sistem penilaian yang berlaku terlalu rumit. Aspek yang dinilai dalam proses pembelajaran terlalu 
banyak. Guru mengalami kesulitan saat melakukan penilaian, terutama untuk penilaian sikap, sehingga proses penilaian seringkali mengganggu fokus guru dalam mengajar yang mengakibatkan tidak efektifnya dalam penilaian tersebut. Guru mengakui bahwa proses penilaian sikap yang dilakukan masih dipengaruhi oleh unsur subjektivitas.

Selain itu juga guru ini kurang mengikuti pelatihan-pelatihan yang berulangulang tentang penilaian autentik sehingga pengetahuan dan penguasaan dalam penilaian autentik masih kurang. Kejadian ini tidak sesuai dengan juknis Permendikbud Nomor 22 Tahun 2016 dalam penilaian proses dan hasil pembelajaran secara autentik.

Sama halnya dengan penelitian yang dilakukan oleh Vidriana (2018), dalam jurnal dengan judul Pengembangan Modul Pelatihan Pengelolaan Penilaian Autentik Guru IPA SMP ia menemukan bahwa masih terdapat kesenjangan dalam melakukan penilaian autentik karena kurangnya pengetahuan dalam melakukan penilaian tersebut dikarenakan salah satu persoalan mendasar yang dihadapi guru-guru IPA SMP adalah minimnya kesempatan mengikuti pelatihan kurikulum 2013 tentang penilaian autentik. Pelatihanpelatihan yang pernah diikuti oleh guru-guru IPA belum sepenuhnya menjawab kebutuhan para guru mengenai penilaian autentik dalam kurikulum 2013. Namun pada Guru 1 dan Guru 3 sudah mengacu pada standar/juknis.

Dengan demikian dirumuskan bahwa evaluasi hasil implementasi K. 13 bidang studi biologi di SMA Negeri 1 Waingapu dapat diketahui bahwa belum maksimal mencapai tujuan program yang mengacu pada standar tersebut.

Berbeda dengan penelitian yang dilakukan oleh E Mulyasa, (2019), dalam jurnal dengan judul Implementasi Sistem Penilaian Kurikulum 2013 Di Sekolah Menengah ia mendapatkan hasil bahwa dalam penilaian sikap dilakukan dengan menggunakan teknik observasi, penilaian diri, dan penilaian antar teman. Hasil penilaian sikap dilaporkan kepada peserta didik dan orang tua dalam bentuk predikat A (amat baik), B (baik), dan C (kurang baik), disertai dengan deskripsinya, dengan demikian pada penilaian sikap dilakukan secara komprehensif.

Elwien Sulistya N. (2015), dalam jurnal dengan judul Implementasi Kurikulum 2013 Di Sekolah Dasar mendapatkan hasil bahwa pada penilaian sikap dilakukan secara komprehensif pada setiap pembelajaran, selain itu juga penilaian sikap dilakukan oleh orang tua peserta didik dalam mengawasi dan membantu anak ketika belajar di rumah. Oleh karena itu ketercapaian penilaian sikap perlu adanya kinerja guru dan orang tua yang baik agar menghasilkan sumber daya manusia yang berkompetensi.

\section{SIMPULAN DAN SARAN Simpulan}

Dari hasil penelitian dan pembahasan maka dapat disimpulkan oleh peneliti antara lain:

1. Pada desain perencanaan implementasi K. 13 bidang studi biologi sudah perpatokan pada peraturan yang sudah ditetapkan pada Permendikbud No. 22 tahun 2016, tetapi masih ada beberapa hal yang senjang dimana dalam penyusunan materi/bahan ajar secara berurutan, analitis, berhubungan dengan kondisi dan aktual.

2. Pada instalasi pembelajaran evaluasi kinerja guru biologi sudah mengacu pada standar yang berpedoman pada aspek komponen perencanaan, pelaksanaan, dan evaluasi yang menunjukkan tidak adanya kesenjangan.

3. Pada proses pelaksanaan sudah berpedoman pada juknis tersebut namun masih ditemui kesenjangan pada pelaksanaan atau penyampaian materi secara berurutan, analitis, berhubungan dengan kondisi dan aktual, maupun dalam 
kegiatan pendahuluan, kegiatan inti dan kegiatan penutup.

4. Pada hasil pembelajaran sudah melaksanakan penilaian autentik dalam proses belajar mengajar yaitu penilaian kognitif, afektif, dan psikomotor. Tetapi masih ditemui senjang terutama pada penilaian afektif tidak dinilai pada semua peserta didik namun hanya pada siswa yang paling aktif dan paling tidak aktif saja sedangkan yang lain dirata-ratakan saja. Maka disimpulkan bahwa sudah berpatokan pada peraturan yang ditentukan tetapi belum adanya ketercapaian secara maksimum.

\section{Saran}

Adapun saran dari penelitian ini ialah:

1. Bagi pemimpin dan wakasek kurikulum dapat memakai hasil penelitian ini sebagai bekal dalam memperbaiki penerapan K. 13 sehingga dapat ditemukan bahwa program $\mathrm{K}$ 13 tercapai atau belum.

2. Guru diharapkan selalu berusaha untuk melaksanakan program pembelajaran sesuai dengan perencanaan RPP yang sudah dibuat sebelumnya.

3. Guru dalam penyusunan materi/bahan ajar perlu mempertimbangkan keberurutannya, analitis, berhubungan dengan kondisi dan aktual.

4. Guru dalam melaksanakan penilaian afektif siswa perlu dinilai semua siswa sehingga maksimal dan sesuai dengan juknis.

\section{Rekomendasi}

Masukan bagi pendidik bidang studi biologi diharapkan program perbaikan pada tahap desain, proses, dan hasil dalam menerapkan K 13 agar disesuaikan dengan Permendikbud No. 22 tahun 2016 tentang Standar Proses Pendidikan Dasar dan Menengah.

\section{DAFTAR PUSTAKA}

Bintari, dkk. (2014). Pembelajaran Bahasa Indonesia Berdasarkan Pendekatan
Saintifik (Problrm Basaed Learning) Sesuai Kurikulum 2013 Di Kelas VII SMP Negeri 2 Amlapura. Jurnal Program Pascasarjana Universitas Pendidikan Ganesa Program Studi Pendidikan Bahasa Indonesia. 3(1). Tersedia pada: http://oldpasca.undiksha.ac.id/ejournal/index.php/jurnal_bahasa/article /view/1185.

Djumali \& Erlina W. (2018). Implementasi Pendidikan Karakter Kurikulum 2013 di SMK Batik 1 Surakarta. Jurnal Pendidikan Ilmu Sosial. 28(1): 31-40. Tersedia pada: http://journals.ums.ac.id/index.php/jpis /article/view/6770.

E. Mulyasa, D. (2019). Implementasi Kurikulum 2013 Di Sekolah Menengah Pertama. Jurnal Nusantara Education Review. 1(2): 57-64. Tersedia pada: http://ojs.spsuninus.ac.id/index.php/ner /article/view/67/47.

Fadlillah, M. 2014. Implementasi Kurikulum 2013 dalam Pembelajaran SD/MI/SMP/MTS, \& SMA/MA. Yogyakarta: Ar-Ruzz Media.

Gusti, S. (2017). Analisis Hasil Implementasi Kurikulum 2013 dalam Aspek Sikap, Pengetahuan, dan Keterampilan Pada Mata pelajaran Biologi SMA di Kabupaten Sleman Yogyakarta. Jurnal Prodi Pendidikan Biologi. 6(5): 312322. Tersedia pada: http://journal.student.uny.ac.id/ojs/ojs/i ndex.php/pbio/article/view/8127/0.

Kemendikbud. 2016. Permendikbud 22 tahun 2016 tentang Standar Proses Pendidikan Dasar dan Menengah. Jakarta: Kementrian Pendidikan dan Kebudayaan.

Karmana, Oman. 2007. Cerdas Belajar Biologi. Bandung: Grafindo Media Pertama. 
Majid, Abdul. 2011. Perencanaan Pembelajaran, Mengembangkan Standar Kompetensi Guru. Bandung: Remaja Rosda Karya.

Markle, R., \& O’Banion, T. (2014). Assessing Affective Factors To Improve Retention and Completion. Learning Abstracts. 17(11). Tersedia pada: Retrieved from https://www.ets.org/s/successnavigator/ pdf/learning_abstracts_markle_o banion.pdf.

Mukminan. 2013. Implementasi Kurikulum 2013. Yogyakarta: Universitas Negeri Yogyakarta.

Pratiwi, U., \& Farida, E. (2015). Pengembangan Instrumen Penilaian HOTS Berbasis Kurikulum 2013 terhadap Sikap Disiplin. Jurnal Penelitian dan Pembelajaran IPA. 1(1): 123-142. Tersedia pada: http://jurnal.untirta.ac.id/index.php/JPP I/article/view/330.

Retnawati, H. (2015). Hambatan Guru Matematika Sekolah Menengah Pertama dalam Menerapkan kurikulum Baru. Jurnal Cakrawala Pendidikan. Th. XXXIV (3): 390-403. Tersedia pada:

http://staff.uny.ac.id/sites/default/files/ penelitian/heri-retnawati-dr/cp-heriretnawati-20153-7694-19613-1-pb.pdf.

Rose Clare \& Glenn F. Nyre. 1977. The Practice of Evaliation. Princetion: Education Testing Service; Princeton, New Jersey: ERIC/TM Report 65.

Roza, A. dkk (2017). Implementasi Kurikulum 2013 Bagi Guru Kimia Di SMA Negeri
Sekota Bengkulu. Jurnal Pendidikan dan Ilmu Kimia. 1(2): 132-135. Tersedia pada:

https://ejournal.unib.ac.id/index.php/al otropjurnal/article/view/3535/1883.

Sanjaya, Wina. (2010). Strategi Pembelajaran Berorientasi Standar Proses Pendidikan. Jakarta : Prenada Media Group.

Setiadi, H. (2016). Pelaksanaan Penilaian Pada Kurikulum 2013. Jurnal Penelitian dan Evaluasi Pendidikan. 20(2): 166-178. Tersedia pada: http://journal.uny.ac.id/index.php/jpep.

Sulistya, E. (2015). Implementasi Kurikulum 2013 Di Sekolah Dasar. Jurnal Manajemen Pendidikan. 25(5): 416423. Tersedia pada: http://ap.fip.um.ac.id/wpcontent/uploads/2015/05/JurnalManajemen-Pendidikan-volume-24no. -5 .pdf\#page $=64$.

Sultoni, A. (2016). Implementasi Kurikulum 2013 Bidang Studi Biologi dalam Mengembangkan Sikap Religius Siswa Di Mandarasah Aliyah. Jurnal Pendidikan Agama Islam. 4(1): 69-91. Tersedia pada: https://media.neliti.com/media/publicat ions/118037-ID-implementasikurikulum-2013-dalam-mengem.pdf.

Oktoviana, V. (2018). Pengembangan Modul Pelatihan Pengelolaan Penilaian Autentik Guru IPA SMP. Jurnal Manajemen Pendidikan. 5(2): 139-151. Tersedia pada: http://ejournal.uksw.edu/kelola/article/ view/1775/1073. 